\title{
A case study on the application of activity-based costing on the magnetic inductor
}

\author{
Nurul Farahin Zamrud ${ }^{1}$, Sri Nur Areena Mohd Zaini ${ }^{1},{ }^{*}$ and Mohd Yazid Abu ${ }^{1}$ \\ ${ }^{1}$ Faculty of Manufacturing \& Mechatronic Engineering Technology, Universiti Malaysia Pahang, 26600 Pahang, Malaysia.
}

ABSTRACT - Speedy improvements in cost accounting since the 1960s have been noticed, particularly after the 1980s, in the percentage of total cost, overhead costs have increased. The problem of overhead allocation was faced by several companies and a disparity between the available methods of overhead allocation was developed. Because of skewed facts about the viability of their orders, goods and clients, traditional cost accounting (TCA) not anymore represents the actual economic reality. Consequently, in the moment of increasingly growing material liquidity and ambiguity, a new costing approach is needed to address the weakness of TCA. The goal of the study is to establish a new costing structure using activity based costing $(A B C)$ method to the magnetic inductor for better precision. The case study is located at electronic industry in Pahang, Malaysia. $A B C$ reports on the costs of manufacturing, selling or funding the goods used in the operations. The job was done correctly by the operator to accomplish the entire mission. The maximum time used by operators is at epoxy application activity which is $44.04 \%$ and the smallest is $0.64 \%$ at oven curing and boundary inspection activity. The highest amount of cost of capacity is epoxy application activity with MYR 1,665,600.00 and the quantity of material utilized is selected as the cost driver. Since the product required volume is up to $10 \%$, production costs are expected to increase by MYR 4,160,614.85 while the unit product cost is forecast at MYR 0.79. Therefore, $\mathrm{ABC}$ is an cost management insightful process and cost control efficient approach.
ARTICLE HISTORY

Received: 26-1-2021

Revised: 1-2-2021

Accepted: 3-3-2021

KEYWORDS

Activity-based costing

Cost driver

Overhead

\section{INTRODUCTION}

High overhead production costs mean that the secret factory is triggered by rising transactions such as the exchange of products and information between industries (Miller and Vollmann, 1985). Traditional cost accounting (TCA) technique are no longer capable of allocating these costs accordingly to goods (Uskonen and Tenhiälä, 2012) and precise cost details are very relevant for decision-making that is used as a root of competitive benefit (Maiga, 2014). Cooper and Kaplan (1988) suggested a brand new perspective to cost accounting, activity-based costing (ABC) to be adopted for intra-company purposes at that time (La Londe and Pohlen, 1996). Costing systems provide decision makers with information on their product cost, product mix, process actions, and expenditure of resources. In the manufacturing sector, different costing approaches are used, such as $\mathrm{ABC}$, which assign a cost for each product, operation and service according to production processes that can offer perspectives into areas for better use of activities as indicators (Helberg et al, 1994).

$\mathrm{ABC}$ is an idea to aid businesses predict the cost of output efficiently (Johnson and Kaplan, 1991). A tool seen in companies for internal management and beneficial for generating simulation situations that take into account product expense, production volume, and diversification of goods, offering subsidies for profit-enhancing decisions. Since profits are the company managers' current main goal, economic drivers are taken into account when implementing the ABC method (Marinho Neto et al, 2018). ABC's central principle is that the operation is the fundamental object and the overall consumption of the commodity is the aggregate of all operations to extend the cost range and make the measurement more precise (Gui, 2019). Via all services that are used to generate goods, this approach calculates the costs of relevant activities. Cost drivers have been used in the implementation of $\mathrm{ABC}$ to distribute the real costs according to the activities involved. The price drivers will be a factor affecting the cost of the operation. In addition, for calculation, unit cost will be recognized as an outcome of $\mathrm{ABC}$. In general, the implementation of $\mathrm{ABC}$ required four simple measures. Activities are determined resource costs are allocated to activities, outputs are defined and operation costs are assigned to outputs. The company must conducted a thorough review of the operational processes for each of the work centres for the first level. In order to generate a production, there may be one or more activities involved in each process. Those activities should be identified and reported clearly. Next, it is important to assign resource costs of all activates found. The company allowed the costs for each operation to be traced back through this phase and to decide why the cost occurred. All the production had to be defined clearly. The products, services and customer can be the very simple outputs. The very last step is to allocate all operating costs using cost drivers to outputs related to the performance consumption. Accurate cost data will be collected via the four basic phases of ABC. Based on the detailed cost details, management will make better decisions (Fito et al, 2018).

Due to its various advantages, $\mathrm{ABC}$ was extensively adopted. In order to make decisions, it provided executives with accurate, timely and reliable information (Alsmadi et al, 2014), classified as an informative tool in cost control and an 
efficient cost reduction technique (Safeiee et al, 2020), gave a further detailed cost of the product than TCA (Kont, 2011), helped to estimate costs during complex processes (Kim et al, 2015), allowed production costs and environmental costs to be accurately calculated (Tsai, 2018), helped to measure the cost of the product or service by allocating The expenses incurred in the operations of development process (Khataie and Bulgak, 2013), provided real cost information to support decision-making management (Gottmann et al, 2013), providing detailed and reliable cost information often needed to take different management decisions (Dwivedi and Chakraborty, 2016), provided detailed planning and control information that contributes to excessive cost reduction (Fang and $\mathrm{Ng}, 2011$ ), presented real cost information that makes decision-making easier for management (Parker, 2016), helped managers to accurately compute cost driver values and to make reliable cost assessments (Kostakis et al, 2011), provided more detailed cost information was given to accurately measure the production cost of our option (Jing and Songqing, 2011), assessed the relative profitability of each business segment (Lau et al, 2016) and all unnecessary tasks of the company have been upgraded (Marinho Neto et al, 2018).

$\mathrm{ABC}$ also allocates overheads such as indirect costs, to goods that follow a different approach compared to TCAs, which assign overhead costs to products without taking into account the scope of the manufacturing processes and their facilities, like administrative offices. Yet, when allocating direct costs, TCA may be considered useful, but indirect costs are disregarded. In 2014, Kolosowski and Chwastyk reported that over the years, overheads have gained greater significance as their share of the overall manufacturing costs of the company has risen from 15 to 45 percent on average. The rise in overheads was primarily due to production process automation and outsourcing services. Figure 1 shows a brief description of how the $\mathrm{ABC}$ operates.

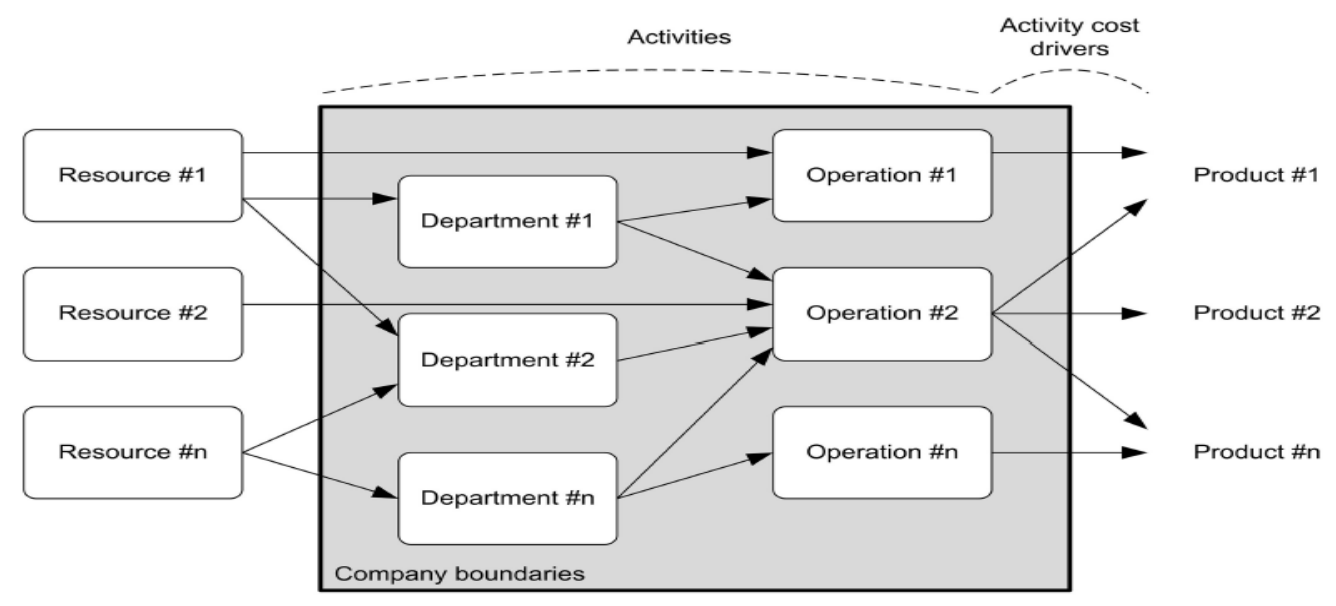

Figure 1. Assigning company's overheads under the ABC system (Marinho Neto et al, 2018).

There are several reports of this in the scientific literature. ABC was commonly employed in many sectors, such as the environment, engineering, healthcare, etc. For engineering based on the ABC principle in an Indian steel plant, a costing model was built for the raw materials management segment (Dwivedi and Chakraborty, 2016). All activities that were acquired from this framework are specifically outlined and conducted under efficiency resources. The steel plant has lowered production costs with successful resource planning. A cost assessment model for cost information for the treatment of assisted reproduction technology in Italy has been designed using an ABC method for healthcare (Cassettari et al, 2016). The outcomes of this model were clearly identified by the real cost information of the specific procedure. Management has also enabled an effective budget to be developed in order to ensure care quality. While in academic sector, there was a strategic management as marketing information by implementing ABC method in a technical college in Bekasi, Indonesia (Hidayat and Prasetyo, 2020). Surprisingly, Zheng and Abu (2019) implemented ABC in the palm oil plantation while the distinctive pattern of crankshaft and the critical and non-critical parameter of crankshaft which defined by Mahalanobis Taguchi System was developed in Abu et al (2018), Nik Mohd Kamil and Abu (2018) and Abu et al (2017). Then they applied ABC as a method of estimation for the remanufacturing cost of crankshaft.

This work aims to improve the precision of the ABC method on the magnetic inducer. Specifically, a workstation is randomly selected to gain all the data required. The amount of time taken in each operation is gathered by interviewing the operators. The cost of resources for labor, maintenance, material and consumable also are collected from the general ledger. Later, cost driver is assigned by considering the suitability of resources and products. Finally, the cost per unit of product is calculated and in comparison with the company's approach for further discussion. Consequently, a conclusion is made through the analysis.

\section{METHODOLOGY}

The initial step of implementing $\mathrm{ABC}$ is to do a manufacturing flow analysis on the production line. In this step, all activities in the production line are described. There are 13 workstations to produce a magnetic inductor as starting from CNC winding until packaging. The production process flow is illustrated as in Figure 2. Each workstation activities are described in detail in a paragraph. 


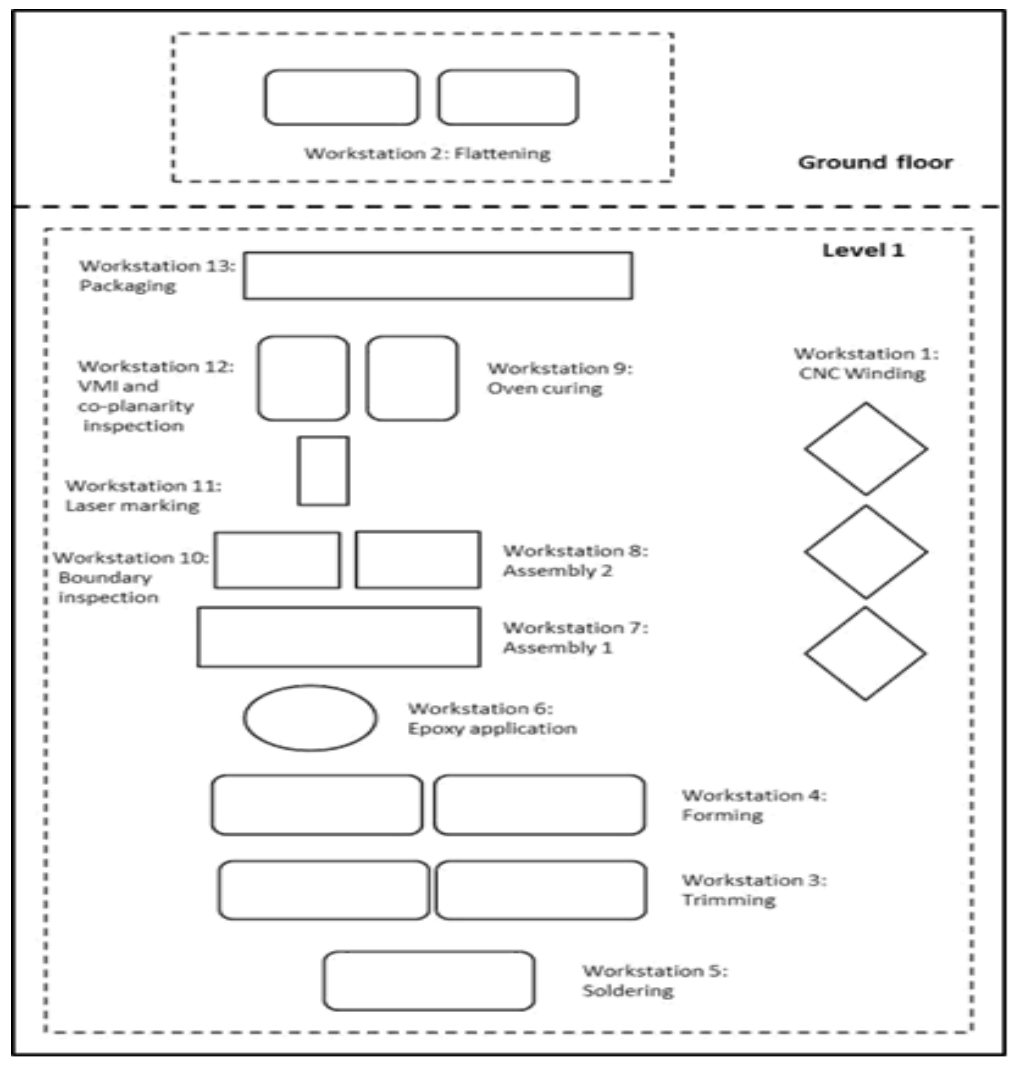

Figure 2. The production process flow.

The process starts with workstation 1 and ends with workstation 13. Note that workstation 2 is only located at level 1 of the ground floor. The manufacturing process starts at workstation 1 which is winding by means of using computer numerical control (CNC) machines. For this workstation, there are three CNC machines. There is a rectangular wire being winded into coil. The wire is pulled from spool into the CNC machine by an auto feeder machine. The wire will be disconnected at the specified area. Next, both ends of the coil are flattened at workstation 2 . There are two hydraulic press machines in this workstation. Firstly, the operators needed to collect coils from workstation 1 . The process started by putting 5 pieces of coil onto flattening fixture and pushing the fixture into the machine. Then, switch button is pushed to execute the flattening process. After the coils are flatten, the fixture is pulled out and the coils are removed. A brush is used to remove any chips from the fixture. Then at workstation 3, the coils undergo trimming process. The process is done by using two pneumatic press machines. It is to trim excess ends of the coils. 2 pieces of coil are put into a trimming fixture and the operators pushed switch buttons to execute the process. A brush is used to clean the jig from unwanted chips after the coils are removed. At workstation 4 , the process is to bend the ends of the coil into $90^{\circ}$. There are two pneumatic press machines used. The operators put 3 pieces of coil into jigs and press the buttons to bend the coils. The jigs are designed to let the coils fall into a container after the bending process. A brush is used to eliminate unwanted chips. The next process is where the ends of the coil are soldered at workstation 5. The coils are picked up and inserted onto the tongs. Until soldering the coils are first immersed in the flux solution. Soldered coils are put into a container and ready to be transferred to next workstation. At workstation 6, epoxy resin is applied onto a material called core. The cores are arranged on magnetic strips before being transferred into machine slots. The strips are manually transferred by operator in between 3-dots and 4-dots application. Meanwhile at workstation 7, the coil from workstation 5 which is the soldering process is assembled with a material called bottom core. The operators need to check for any defects on the coils before proceed with the assembly process. Then, the core and bottom core from workstation 6 and workstation 7 respectively are assembled together for assembly 2 at workstation 8 . This completes the entire assembly phase of an inductor. Each inductor must be clipped to secure the adhesive before going to the next processing station. At workstation 9, the clipped inductors are stored in a curing oven for 30 minutes and cool down for 10 minutes over the fan. The clips are then removed and the inductors are inspected at a workstation 10. The operators slide the inductors using specialized jig made for this workstation to inspect the product dimension. Then, workstation 11 is a laser-marking process on top surface of each inductor. Each inductor undergoes laser marking for 1.8 seconds. This process provides information details of the product to the consumer. At workstation 12,Inductors shall be checked for further evaluation in the event of defects, through Visual and Mechanical Inspection (VMI) and co-planarity inspections. Last but not least, at the last workstation which is packaging, bubble wraps are used to wrap the reels to minimize impact during movements. Then, wrapped reels are packed into boxes and ready to send to customers.

After identifying the activities involved in the development, the correct cost drivers and operations must be defined. The primary cause of manufacturing costs is the cost engine. Management will allow the real causes of an operation to be determined. The third step is to allocate the cost of resources to each task. Firstly, the cost of energy used to run each operation must be calculated. The tasks conducted within the organization are a unit of work performed within the 
organization. First, it is important to forecast and assign the amount of overhead costs expected by such operations as a percentage. In reality, the cost of services, such as wages, supplies and utilities, are already reported in the current accounting system. Overhead costs are split into various operations. In addition, overhead expenses for categories such as consumables, wages, cost of materials and other costs will be assigned based on percentage. The cost data obtained is more precise if the greater the number of categories. The fourth stage will be calculating the cost per operation driver unit. The aim of an activity driver is to estimate the necessary cost of an activity as a price drive. The operation costs or the costs incurred by the object must be the same as the driver. For example, the direct labor cost will lead the labor costs. The larger the direct labor cost, the more jobs are required. The direct labor costs would be twice the cost of a system or service that required two employees to operate. The result will be the list of the operations conducted in the company and the overall cost of activity. If the greater the number of activity drivers of activity costs, the cost obtained is more precise. However, to minimize the cost of uncertainty, there is only one or two operation drivers to be considered. A list of activities for and of the items is prepared as the last step. A cost object is any item for which the management needs a separate cost calculation. If the cost driver consumed multiplies with the cost per unit of the operation driver, gross annual expenditures will be obtained after annual quantity. The effect is a net expense for each object, which contains a list of the product's operations and costs. Accurate profitability would also be reached. As a consequence, using this ABC process, real cost data and proper cost drivers can be collected.

\section{RESULT AND DISCUSSION}

The time the operator spends performing the task is defined for each workstation. By interviewing the operators and by observation, the time spent is taken as an average. The time spent from interviews and observation is revealed in Table 1 for all workstations.

Table 1. Time used for all workstations.

\begin{tabular}{cc}
\hline Activity & Time used (\%) \\
\hline Winding & 16.56 \\
\hline Flattening & 1.27 \\
\hline Trimming & 1.27 \\
\hline Forming & 1.27 \\
\hline Soldering & 12.40 \\
\hline Epoxy application & 44.04 \\
\hline Assembly 1 & 14.60 \\
\hline Assembly 2 & 1.28 \\
\hline Oven curing & 0.64 \\
\hline Boundary inspection & 0.64 \\
\hline Laser marking & 0.65 \\
\hline VMI and co-planarity inspection & 4.09 \\
\hline Packaging & 1.28 \\
\hline Total & 100
\end{tabular}

The largest time spent by operators is at epoxy application workstation which is $44.04 \%$, followed by winding workstation at $16.56 \%$, and assembly 1 workstation at $14.60 \%$. At epoxy application, the time is consumed largely with the application of 3-dots and 4-dots of epoxy on every single core. The number of epoxy applicator plays an important role against the time taken. In order to shorten the time taken, the number of applicators can be increase and can be applied simultaneously at one time. As for winding workstation, the time spent is largely influenced by the speed and the machine mechanism. While for assembly 1, the time spent is largely influenced by the operators. Cost of capacity is to calculate the cost of all the resources such as staff, supervision, infrastructure and technology provided to the division or operation. In this study, the cost of capacity resources of each activity/workstation is calculated in terms of (i) labor costs, (ii) maintenance costs, (iii) material costs, and (iv) consumable costs. The following are descriptions of the expense of each operation and sub-activity. The tables below show the annual expenses for the magnetic inductor production for each workstation. The basic monthly wages of the labor is MYR 1,000. For winding workstation as shown in Table 2, there are 2 operators working daily. The operators have 8 hours and 35 minutes of working hours per day for 5 days per week. For maintenance, the winding workstation has several maintenances to replace machine parts such as micro grinder, adjustable forming slider, and stripper motor. The total maintenance cost is MYR 26,449.89. The material used is rectangular copper wire with dimension of $0.80 \mathrm{~mm} \times 2.3 \mathrm{~mm}$. This work finds that there is no allocated amount of cost for consumable.

Table 2. Labor, maintenance, material and consumable cost for winding workstation. 


\begin{tabular}{cccccc}
\hline Workstation & $\begin{array}{c}\text { Labor } \\
(\mathrm{MYR})\end{array}$ & $\begin{array}{c}\text { Maintenance } \\
(\mathrm{MYR})\end{array}$ & $\begin{array}{c}\text { Material } \\
(\mathrm{MYR})\end{array}$ & $\begin{array}{c}\text { Consumable } \\
(\mathrm{MYR})\end{array}$ & $\begin{array}{c}\text { Cost of all resources } \\
\text { supplied (MYR) }\end{array}$ \\
\hline Winding & $24,000.00$ & $26,449.89$ & $576,000.00$ & nil & $626,449.89$ \\
\hline
\end{tabular}

For flattening workstation as shown in Table 3, there are 4 operators working daily. The operators have 8 hours and 35 minutes of working hours per day for 5 days per week and the cost of labor is MYR 48,000 annually. For maintenance, the flattening workstation has one maintenance which is to replace flexible hose which costs MYR 70. This work finds that there is no allocated amount of material for flattening workstation. The material is from the continuation of previous workstation; winding. The consumable cost is for finger coats used by operators.

Table 3. Labor, maintenance, material and consumable cost for flattening workstation.

\begin{tabular}{cccccc}
\hline Workstation & $\begin{array}{c}\text { Labor } \\
(\mathrm{MYR})\end{array}$ & $\begin{array}{c}\text { Maintenance } \\
(\mathrm{MYR})\end{array}$ & $\begin{array}{c}\text { Material } \\
(\mathrm{MYR})\end{array}$ & $\begin{array}{c}\text { Consumable } \\
\text { (MYR) }\end{array}$ & $\begin{array}{c}\text { Cost of all resources } \\
\text { supplied (MYR) }\end{array}$ \\
\hline Flattening & $48,000.00$ & 70.00 & nil & 144.00 & $48,214.00$ \\
\hline
\end{tabular}

For trimming workstation as shown in Table 4, there are 4 operators working daily. The operators have 8 hours and 35 minutes of working hours per day for 5 days per week. This work finds that there is no allocated amount of maintenance and material, for trimming workstation. There is no maintenance reported for the trimming machine. The material is from the continuation of previous workstation; flattening. The MYR 192 consumable cost is for finger coats and brushes.

Table 4. Labor, maintenance, material and consumable cost for trimming workstation.

\begin{tabular}{cccccc}
\hline Workstation & $\begin{array}{c}\text { Labor } \\
(\text { MYR })\end{array}$ & $\begin{array}{c}\text { Maintenance } \\
\text { (MYR) }\end{array}$ & $\begin{array}{c}\text { Material } \\
\text { (MYR) }\end{array}$ & $\begin{array}{c}\text { Consumable } \\
\text { (MYR) }\end{array}$ & $\begin{array}{c}\text { Cost of all resources } \\
\text { supplied (MYR) }\end{array}$ \\
\hline Trimming & $48,000.00$ & nil & nil & 192.00 & $48,192.00$ \\
\hline
\end{tabular}

For forming workstation in Table 5, there are 4 operators working daily. The operators have 8 hours and 35 minutes of working hours per day for 5 days per week. There are 2 pneumatic machines used for the operation. This work finds that there is no allocated amount of maintenance and material cost for forming workstation. There is no maintenance reported for the pneumatic machine. The material is from the continuation of previous workstation; trimming. The consumable cost of MYR 192 is for finger coats and brushes.

Table 5. Labor, maintenance, material and consumable cost for forming workstation.

\begin{tabular}{cccccc}
\hline Workstation & $\begin{array}{c}\text { Labor } \\
(\mathrm{MYR})\end{array}$ & $\begin{array}{c}\text { Maintenance } \\
(\text { MYR })\end{array}$ & $\begin{array}{c}\text { Material } \\
(\text { MYR })\end{array}$ & $\begin{array}{c}\text { Consumable } \\
(\text { MYR })\end{array}$ & $\begin{array}{c}\text { Cost of all resources } \\
\text { supplied (MYR) }\end{array}$ \\
\hline Forming & $48,000.00$ & nil & nil & 192.00 & $48,192.00$ \\
\hline
\end{tabular}

For soldering workstation, the operators have 8 hours and 35 minutes of working hours per day for 5 days per week. There are 2 operators working daily and the total labor cost is MYR 24,000 annually. This work as in Table 6 finds that there is no allocated amount of maintenance and material cost for soldering workstation. For consumable cost, this workstation uses solder bar, rosin flux solution, masks, and rubber gloves. The cost of consumable for this workstation is MYR 445,064.32.

Table 6. Labor, maintenance, material and consumable cost for soldering workstation.

\begin{tabular}{cccccc}
\hline Workstation & $\begin{array}{c}\text { Labor } \\
(\mathrm{MYR})\end{array}$ & $\begin{array}{c}\text { Maintenance } \\
\text { (MYR) }\end{array}$ & $\begin{array}{c}\text { Material } \\
(\mathrm{MYR})\end{array}$ & $\begin{array}{c}\text { Consumable } \\
\text { (MYR) }\end{array}$ & $\begin{array}{c}\text { Cost of all resources } \\
\text { supplied (MYR) }\end{array}$ \\
\hline Soldering & $24,000.00$ & nil & nil & $445,064.32$ & $469,064.32$ \\
\hline
\end{tabular}

In Table 7, for epoxy application workstation, the operators have 8 hours and 35 minutes of working hours per day for 5 days per week, there are 2 operators working daily. This work finds out that there is no allocation of cost for maintenance. The material used at this workstation is core that cost MYR 1,440,000 while epoxy resin, masks, finger coats, and tissues are categorized as consumables with the cost of MYR 201,600.

Table 7. Labor, maintenance, material and consumable cost for epoxy application workstation.

\begin{tabular}{cccccc}
\hline Workstation & $\begin{array}{c}\text { Labor } \\
(\mathrm{MYR})\end{array}$ & $\begin{array}{c}\text { Maintenance } \\
(\text { MYR })\end{array}$ & $\begin{array}{c}\text { Material } \\
(\text { MYR })\end{array}$ & $\begin{array}{c}\text { Consumable } \\
(\text { MYR })\end{array}$ & $\begin{array}{c}\text { Cost of all resources } \\
\text { supplied (MYR) }\end{array}$ \\
\hline $\begin{array}{c}\text { Epoxy } \\
\text { application }\end{array}$ & $24,000.00$ & nil & $1,440,000.00$ & $201,600.00$ & $1,665,600.00$ \\
\hline
\end{tabular}


For assembly 1 workstation, the operators have 8 hours and 35 minutes of working hours per day for 5 days per week. There are 6 operators working daily and the total labor cost is MYR 72,000 annually. Table 8 shows that there is no cost allocated for maintenance for this workstation. Bottom core is used as material for this workstation with the cost of MYR 480,000. For consumables, the operators use finger coats and masks. The cost of consumable is MYR 403.20.

Table 8. Labor, maintenance, material and consumable cost for assembly 1 workstation.

\begin{tabular}{cccccc}
\hline Workstation & $\begin{array}{c}\text { Labor } \\
\text { (MYR) }\end{array}$ & $\begin{array}{c}\text { Maintenance } \\
\text { (MYR) }\end{array}$ & $\begin{array}{c}\text { Material } \\
\text { (MYR) }\end{array}$ & $\begin{array}{c}\text { Consumable } \\
\text { (MYR) }\end{array}$ & $\begin{array}{c}\text { Cost of all resources } \\
\text { supplied (MYR) }\end{array}$ \\
\hline Assembly 1 & $72,000.00$ & nil & $480,000.00$ & 403.20 & $552,403.20$ \\
\hline
\end{tabular}

For assembly 2 workstation, the operators have 8 hours and 35 minutes of working hours per day for 5 days per week. There are 4 operators working daily. Referring to Table 9, there is no allocated amount for maintenance and material for this workstation as the assembly process is done manually by the operators and there is no new material used. For consumable cost of MYR 268.80, the operators use finger coats and masks.

Table 9. Labor, maintenance, material and consumable cost for assembly 2 workstation.

\begin{tabular}{cccccc}
\hline Workstation & $\begin{array}{c}\text { Labor } \\
(\mathrm{MYR})\end{array}$ & $\begin{array}{c}\text { Maintenance } \\
(\mathrm{MYR})\end{array}$ & $\begin{array}{c}\text { Material } \\
(\mathrm{MYR})\end{array}$ & $\begin{array}{c}\text { Consumable } \\
\text { (MYR) }\end{array}$ & $\begin{array}{c}\text { Cost of all resources } \\
\text { supplied (MYR) }\end{array}$ \\
\hline Assembly 2 & $48,000.00$ & nil & nil & 268.80 & $48,268.80$ \\
\hline
\end{tabular}

For oven curing workstation, the operators have 8 hours and 35 minutes of working hours per day for 5 days per week. There are 2 operators working daily which totalled up to MYR 24,000 labor cost annually as stated in Table 10. There is no allocated amount of maintenance and material cost. Gloves are used by the operators and are categorized under consumable cost with amount of MYR 24.00.

Table 10. Labor, maintenance, material and consumable cost for oven curing workstation.

\begin{tabular}{cccccc}
\hline Workstation & $\begin{array}{c}\text { Labor } \\
(\mathrm{MYR})\end{array}$ & $\begin{array}{c}\text { Maintenance } \\
(\mathrm{MYR})\end{array}$ & $\begin{array}{c}\text { Material } \\
(\mathrm{MYR})\end{array}$ & $\begin{array}{c}\text { Consumable } \\
(\mathrm{MYR})\end{array}$ & $\begin{array}{c}\text { Cost of all resources } \\
\text { supplied (MYR) }\end{array}$ \\
\hline Oven curing & $24,000.00$ & nil & nil & 24.00 & $24,024.00$ \\
\hline
\end{tabular}

Cost for labor, maintenance, material and consumable cost for boundary inspection workstation is shown in Table 11. The operators have 8 hours and 35 minutes of working hours per day for 5 days per week. There are 2 operators working daily. There is no maintenance done to the jig for this workstation as well as the cost on material. There is amount of MYR 134.40 of consumable that comprises of finger coats and face masks.

Table 11. Labor, maintenance, material and consumable cost for boundary inspection workstation.

\begin{tabular}{cccccc}
\hline Workstation & $\begin{array}{c}\text { Labor } \\
(\text { MYR })\end{array}$ & $\begin{array}{c}\text { Maintenance } \\
(\text { MYR })\end{array}$ & $\begin{array}{c}\text { Material } \\
(\text { MYR })\end{array}$ & $\begin{array}{c}\text { Consumable } \\
\text { (MYR) }\end{array}$ & $\begin{array}{c}\text { Cost of all resources } \\
\text { supplied (MYR) }\end{array}$ \\
\hline $\begin{array}{c}\text { Boundary } \\
\text { inspection }\end{array}$ & $24,000.00$ & nil & nil & 134.40 & $24,134.40$ \\
\hline
\end{tabular}

For laser marking workstation, the operators have 8 hours and 35 minutes of working hours per day for 5 days per week. There are 2 operators working daily. For maintenance, as stated in Table 12, the maintenance cost is MYR 626.53. This workstation has replaced stepper motor and vacuum filter. However, there is no allocated amount for material and consumable recorded for this workstation.

Table 12. Labor, maintenance, material and consumable cost for laser marking workstation.

\begin{tabular}{cccccc}
\hline Workstation & $\begin{array}{c}\text { Labor } \\
(\mathrm{MYR})\end{array}$ & $\begin{array}{c}\text { Maintenance } \\
(\mathrm{MYR})\end{array}$ & $\begin{array}{c}\text { Material } \\
(\mathrm{MYR})\end{array}$ & $\begin{array}{c}\text { Consumable } \\
\text { (MYR) }\end{array}$ & $\begin{array}{c}\text { Cost of all resources } \\
\text { supplied (MYR) }\end{array}$ \\
\hline Laser marking & $24,000.00$ & 626.53 & nil & nil & $24,626.53$ \\
\hline
\end{tabular}

For co-planarity and VMI testing workstation, the operators have 8 hours and 35 minutes of working hours per day for 5 days per week. There are 2 operators working daily. According to Table 13, there is no allocated amount of cost for maintenance and material recorded while for consumable, the cost of MYR 130,824.00 are spent for reels, carrier tapes and brushes.

Table 13. Labor, maintenance, material and consumable cost for co-planarity and VMI test workstation. 


\begin{tabular}{cccccc}
\hline Workstation & $\begin{array}{c}\text { Labor } \\
(\text { MYR })\end{array}$ & $\begin{array}{c}\text { Maintenance } \\
(\text { MYR })\end{array}$ & $\begin{array}{c}\text { Material } \\
(\text { MYR })\end{array}$ & $\begin{array}{c}\text { Consumable } \\
\text { (MYR) }\end{array}$ & $\begin{array}{c}\text { Cost of all } \\
\text { resources } \\
\text { supplied (MYR) }\end{array}$ \\
\hline $\begin{array}{c}\text { Co-planarity and } \\
\text { VMI test }\end{array}$ & $24,000.00$ & nil & nil & $130,824.00$ & $154,824.00$ \\
\hline
\end{tabular}

Table 14 shows cost details for packaging workstation. The operators have 8 hours and 35 minutes of working hours per day for 5 days per week. There are 2 operators working daily to pack products to be shipped out. For consumables, MYR 24,384.00 is due to two types of boxes used, bubble wraps and tapes.

Table 14. Labor, maintenance, material and consumable cost for packaging workstation.

\begin{tabular}{cccccc}
\hline Workstation & $\begin{array}{c}\text { Labor } \\
(\text { MYR })\end{array}$ & $\begin{array}{c}\text { Maintenance } \\
(\text { MYR })\end{array}$ & $\begin{array}{c}\text { Material } \\
(\text { MYR })\end{array}$ & $\begin{array}{c}\text { Consumable } \\
(\text { MYR })\end{array}$ & $\begin{array}{c}\text { Cost of all } \\
\text { resources } \\
\text { supplied (MYR) }\end{array}$ \\
\hline Packaging & $24,000.00$ & nil & nil & $24,384.00$ & $48,384.00$ \\
\hline
\end{tabular}

Table 15 shows the total expenses of labor, maintenance, material and consumable at MYR 456,000.00, MYR 27,146.42, MYR 2,496,000.00 and MYR 803,230.72 respectively. The highest amount of cost allocated is for material, followed by consumable cost. The grand total for magnetic inductor production is MYR 3,782,377.14.

Table 15. Total labor, maintenance, material and consumable cost for all workstations.

\begin{tabular}{ccccc}
\hline Workstation & Labor (MYR) & $\begin{array}{c}\text { Maintenance } \\
(\text { MYR })\end{array}$ & Material (MYR) & Consumable (MYR) \\
\hline Total & RM456,000.00 & RM27,146.42 & RM2,496,000.00 & RM803,230.72 \\
\hline Grand total & & RM 3,782,377.14 & \\
\hline
\end{tabular}

The cost driver is identified by making assumption that the time utilized by each operator at each workstation takes about the same level of effort. It is chosen based on the consideration of the cost that influence the most in the workstation. Next, the ABC system calculated the following cost driver rates as shown in Table 16. Table 16 shows the cost driver rates for the magnetic inductor production using $\mathrm{ABC}$. The cost driver quantity is the estimated quantities of products produced for a year in all 13 activities. Cost driver rates are calculated by dividing the assigned cost and the cost quantity driver for each activity.

Table 16. Cost driver rates for all workstations.

\begin{tabular}{lcccc}
\hline \multicolumn{1}{c}{ Activity } & Cost driver & $\begin{array}{c}\text { Assigned cost } \\
\text { (MYR) }\end{array}$ & $\begin{array}{c}\text { Cost driver Cost driver } \\
\text { quantity }\end{array}$ \\
& & $626,449.89$ & $8,697,600$ & 0.07 \\
\hline 1. Winding & Amount of raw material (g) & MYR) \\
\hline 2. Flattening & Hydraulic press machine (frequency) & $48,214.00$ & 960,000 & 0.05 \\
\hline 3. Trimming & Pneumatic machines (frequency) & $48,192.00$ & $2,400,000$ & 0.02 \\
\hline 4. Forming & Pneumatic machines (frequency) & $48,192.00$ & $2,400,000$ & 0.02 \\
\hline 5. Soldering & Amount of material used (g) & $469,064.32$ & $2,400,000$ & 0.20 \\
\hline 6. Epoxy application & Amount of material used (g) & $1,665,600.00$ & $4,800,000$ & 0.35 \\
\hline 7. Assembly 1 & Amount of material (quantity) & $552,403.20$ & $4,800,000$ & 0.12 \\
\hline 8. Assembly 2 & Amount of material (quantity) & $48,268.80$ & $4,800,000$ & 0.01 \\
\hline 9. Oven curing & Clipping process (frequency) & $24,024.00$ & $4,800,000$ & 0.01 \\
\hline 10. Boundary inspection & Product items (quantity) & $24,134.40$ & $4,800,000$ & 0.01 \\
\hline 11. Laser marking & Laser marking machine (frequency) & $24,626.53$ & $4,800,000$ & 0.01 \\
\hline 12. VMI and co-planarity inspection & Inspection (frequency) & $154,824.00$ & $4,800,000$ & 0.03 \\
\hline 13. Packaging & Product items (quantity) & $48,384.00$ & $4,800,000$ & 0.01 \\
\hline \multicolumn{1}{c}{ Total } & & $3,782,377.14$ & &
\end{tabular}

Using the product cost information on 2018, the product cost can be forecasted. For example, in the following year, the demand of the magnetic inductor increases as much as $10 \%$; while maintaining the production line process, number of labor and equipment, how much is the product cost? Table 17 shows the forecast of product cost respect to the demand quantity using cost rate. The production line is expected to produce 5,280,000 quantities of magnetic inductor. The overall production cost is expected to be MYR 4,160,614.85 while the unit product cost is forecast at MYR 0.79 as the product demand is increased by $10 \%$. 
Table 17. Magnetic inductor forecast cost.

\begin{tabular}{|c|c|c|c|c|}
\hline Activity & Activity cost driver & $\begin{array}{c}\text { Cost } \\
\text { driver rate } \\
(\mathrm{MYR})\end{array}$ & $\begin{array}{c}\text { Cost } \\
\text { driver } \\
\text { quantity }\end{array}$ & $\begin{array}{c}\text { Total cost } \\
\text { (MYR) }\end{array}$ \\
\hline 1. Winding & Amount of raw material $(\mathrm{g})$ & 0.07 & $9,567,360$ & $689,094.88$ \\
\hline 2. Flattening & Hydraulic press machine (frequency) & 0.05 & $1,056,000$ & $53,035.40$ \\
\hline 3. Trimming & Pneumatic machines (frequency) & 0.02 & $2,640,000$ & $53,011.20$ \\
\hline 4. Forming & Pneumatic machines (frequency) & 0.02 & $2,640,000$ & $53,011.20$ \\
\hline 5. Soldering & Amount of material used $(\mathrm{g})$ & 0.20 & $2,640,000$ & $515,970.75$ \\
\hline 6. Epoxy application & Amount of material used (g) & 0.35 & $5,280,000$ & $1,832,160.00$ \\
\hline 7. Assembly 1 & Amount of material (quantity) & 0.12 & $5,280,000$ & $607,643.52$ \\
\hline 8. Assembly 2 & Amount of material (quantity) & 0.01 & $5,280,000$ & $53,095.68$ \\
\hline 9. Oven curing & Clipping process (frequency) & 0.01 & $5,280,000$ & $26,426.40$ \\
\hline 10. Boundary inspection & Product items (quantity) & 0.01 & $5,280,000$ & $26,547.84$ \\
\hline 11. Laser marking & Laser marking machine (frequency) & 0.01 & $5,280,000$ & $27,089.18$ \\
\hline 12. VMI and co- planarity inspection & Co-planarity inspection (frequency) & 0.03 & $5,280,000$ & $170,306.40$ \\
\hline \multirow[t]{3}{*}{ 13. Packaging } & Product items (quantity) & 0.01 & $5,280,000$ & $53,222.40$ \\
\hline & Total $(\mathrm{RM})$ & & & $4,160,614.85$ \\
\hline & Unit (RM) & & & 0.79 \\
\hline
\end{tabular}

Throughout the process, the current company cost information is analysed and compared with cost information by ABC method. It is discovered that the company applied their costing on activity based rather than volume based. Lead time for each workstation is used to generate the product cost. Table 18 shows the cycle time for a product process to be completed. The cycle time for each activity is collected. The total time for all activities is 0.7250 hours. There is a $20 \%$ allowance of cost added to the total cost for allocation of maintenance, operators' short break and unproductive time. Thus, the grand total time for this process to be completed is 0.87 hours.

Table 18. Product cycle time.

\begin{tabular}{ccc}
\hline Step & Process & Cycle Time (Hours) \\
\hline 1. & Winding & 0.1312 \\
\hline 2. & Label leadouts & 0.0056 \\
\hline 3. & Cut lead \& bend wires & 0.0056 \\
\hline 4. & Oven curing & 0.0006 \\
\hline 5. & Solder coat pins & 0.0052 \\
\hline 6. & Pre-solder leadouts & 0.1597 \\
\hline 7. & Hook up leadouts to pin & 0.0944 \\
\hline 8. & Pin soldering & 0.0278 \\
\hline 9. & Inspection & 0.0662 \\
\hline 10. & Test & 0.002 \\
\hline 11. & Assembly & 0.0587 \\
\hline 12. & Inductance test & 0.0185 \\
\hline 13. & TSE application & 0.0066 \\
\hline 14. & Oven curing & 0.0006 \\
\hline 15. & Final test & 0.0667 \\
\hline 16. & Full final inspection & 0.0750 \\
\hline 17. & Packaging & 0.0005 \\
\hline & Total & 0.7250 \\
\hline & 20\% Allowance & 0.1450 \\
\hline & Grand total & 0.87 \\
\hline
\end{tabular}

The company's costing structure for product is as shown in Table 19. MHU stands for material handling unit. The cycle time of all working stations is 0.87 hours. BOM stands for bill of material. It is the build-up of material costs used by each process operation. The total BOM cost for this product is US\$1.6895. LOH is stands for labor and overhead that identified with multiplication of MHU and LOH rate which is US\$ 4.0. From Table 19, 3.48 of LOH is the result of multiplication of 0.87 (MHU) with US\$ 4.0. Finally, the total cost is the summation of LOH and BOM, US\$ 5.1695.

Table 19. The product total cost. 


\begin{tabular}{ccccc}
\hline Product No. & MHU & BOM & LOH US\$ 4.0 & Total cost US \$ \\
\hline XXX & 0.87 & 1.6895 & 3.48 & 5.1695 \\
\hline
\end{tabular}

Nevertheless, this section reveals the strength of $\mathrm{ABC}$ throughout the implementation process at the production line. ABC provides information on the cost drivers as shown in Table 16. All cost drivers of the 13 workstations are identified. The company may have implemented the costing using activity based however, the cost drivers are not significantly pointed out. Meanwhile, ABC method is able to point out cost drivers in every workstation.

\section{CONCLUSION}

The novelty of this work is the application of $\mathrm{ABC}$ has been tested in the electronic industry. The time used by the operator to accomplish the work was successfully obtained. The highest time used by operators is at epoxy application activity which is $44.04 \%$ and the smallest is $0.64 \%$ at oven curing and boundary inspection activity. The highest amount of cost of capacity is epoxy application activity with MYR 1,665,600.00. The overall production cost is expected to be MYR 4,160,614.85 while the unit product cost is forecast at MYR 0.79 as the product demand is increased by $10 \%$. Therefore, $\mathrm{ABC}$ is a cost accounting insightful approach and an efficient cost control technique.

The limitation of this work is the time spent for each activity as shown in Table 1 is collected through interview on targeted person. Then duration might be very accurate if all the workers involved in this study.

\section{ACKNOWLEDGEMENT}

For the financial assistance under Research Grant project No. RDU1903105, the authors like to thank the Universiti Malaysia Pahang.

\section{REFERENCES}

Abu, M.Y., Jamaludin, K.R. \& Zakaria, M.A. (2017). Characterisation of activity based costing on remanufacturing crankshaft. International Journal of Automotive and Mechanical Engineering, 14(2), 4211-4224.

Abu, M.Y., Mohd Nor, E.E. \& Abd Rahman, M.S. (2018). Costing improvement of remanufacturing crankshaft by integrating Mahalanobis-Taguchi System and Activity based Costing. IOP Conference Series: Materials Science and Engineering, 342, 1-10.

Alsmadi, M., Almani, A. \& Khan, Z. (2014). Implementing an integrated ABC and TOC approach to enhance decision making in a Lean context. International Journal of Quality \& Reliability Management, 31(8), 906-920.

Cassettari, L., Mosca, M., Mosca, R., Rolando, F., Costa, M. \& Pisaturo, V. (2016). IVF cycle cost estimation using Activity Based Costing and Monte Carlo simulation. Health Care Manag Sci, 19(1), 20-30.

Cooper, R. \& Kaplan, R.S. (1988). How cost accounting distorts product costs. Manag. Account, 69, 20-27.

Dwivedi, R. \& Chakraborty, S. (2016). Adoption of an activity based costing model in an Indian steel plant. Verslas: teorija ir praktika, 17(4), 289-298.

Dwivedi, R. \& Chakraborty, S. (2016). Adoption of an activity based costing model in an Indian steel plant. Verslas: teorija ir praktika, 17(4), 289-298.

Fang, Y. \& Ng, S.T. (2011). Applying activity-based costing approach for construction logistics cost analysis. Construction Innovation, 11(3), 259-281.

Fito, M.A., Llobet J. \& Cuguero, N. (2018). The activity-based costing model trajectory: A path of lights and shadows. Intangible Capital, 14(1), 146-161.

Gottmann, J., Pfeffer, M. \& Sihn, W. (2013). Process oriented production evaluation. Procedia CIRP, 12, $336-341$.

Gui, F., Ren, S., Zhao, Y., Zhou, J., Xie, Z., Xu, C. \& Zhu, F. (2019). Activity-based allocation and optimization for carbon footprint and cost in product lifecycle. Journal of Cleaner Production, 236, 117627.

Helberg, C., Galletly, J. \& Bicheno, J. (1994). Simulating activity-based costing. Indus Manag Data Syst, 94(9), 3-8.

Hidayat, W.W. \& Prasetyo, E.T. (2020). Strategic management implementation of the activity base costing method in higher education as marketing information : A case study of the technical college in Bekasi, Indonesia. Solid State Technology, 63(5), 4200-4205.

Jing, H. \& Songqing, L. (2011). The research of environmental costs based on activity based cost. Procedia Environmental Sciences, 10, 147-151.

Johnson, H.T. \& Kaplan, R.S. (1991). Relevance Lost: the Rise and Fall of Management Accounting. Harvard Business Press.

Khataie, A.H. \& Bulgak, A.A. (2013). A cost of quality decision support model for lean manufacturing: activity-based costing application. International Journal of Quality \& Reliability Management, 30(7), 751-764.

Kim, S., Ko, W. \& Bang, S. (2015). Assessment of activity-based pyro process costs for an engineering-scale facility in Korea. Nuclear Engineering and Technology, 47(7), 849-858.

Kolosowski, M. \& Chwastyk, P. (2014). Economic aspects of company processes improvement. Procedia Engineering, 69, 222-230.

Kont, K.R. (2011). New cost accounting models in measuring of library employees' performance. Library Management, $33(1 / 2), 50-65$.

Kostakis, H., Albayrak, T., Boskou, G. \& Palisidis, G. (2011). Modelling activity-based costing in restaurants. Journal of 
Modelling in Management, 6(3), 243-257.

La Londe, B.J. \& Pohlen, T.L. (1996). Issues in supply chain costing. The International Journal of Logistics Management, 7(1), 1-12.

Lau, H., Nakandala, D., Samaranayake, P. \& Shum, P. (2016). A hybrid multi-criteria decision model for supporting customer-focused profitability analysis. Industrial Management \& Data Systems, 116(6), 1105-1130.

Maiga, A.S. (2012). The effects of information technology integration on manufacturing financial performance: the role of cost control systems. Advances in Management Accounting, 21, 183-206.

Marinho Neto, H.F., Agostinho F., Almeida, C.M.V.B., Moreno García, R.R. \& Giannetti, B.F. (2018). Activity-based costing using multicriteria drivers: an accounting proposal to boost companies toward sustainability. Frontiers in Energy Research, 36(6), 1-12.

Marinho Neto, H.F., Agostinho, F., Almeida, C.M.V.B., Moreno García. R,R, \& Giannetti, B.F. (2018). Activity-based costing using multicriteria drivers: an accounting proposal to boost companies toward sustainability. Front. Energy Res, 6,36.

Miller, J.G. \& Vollmann, T.E. (1985). The hidden factory. Harvard Business Review, 63(5), 142-150.

Nik Mohd Kamil, N.N. \& Abu, M.Y. (2018). Integration of mahalanobis-taguchi system and activity based costing for remanufacturing decision. Journal of Modern Manufacturing Systems and Technology, 1, 39-51.

Parker, L.D. (2016). From scientific to activity based office management: a mirage of change. Journal of Accounting \& Organizational Change, 12(2), 177-202.

Safeiee, F.L.M., Saad, S.K.M. and Abu, M.Y. (2020). A case study on the application of activity-based costing on the inductor component. Jurnal Teknik Industri, 10(3),248-254.

Tsai, W.-H. (2018). Carbon taxes and carbon right costs analysis for the tire industry. Energies, 11(8), 1-22.

Uskonen, J. \& Tenhiälä, A. (2012). The price of responsiveness: cost analysis of change orders in make-to-order manufacturing. International Journal of Production Economics, 135(1), 420-429.

Zaini, S.N.A.M., Zheng, C.W. \& Abu, M.Y. (2020). Costing structure improvement using activity based costing in palm oil plantation of Malaysia. Journal of Modern Manufacturing Systems and Technology, 4(1), 95-109.

Zamrud, N.F. \& Abu, M.Y. (2020). Comparative study: activity based costing and time driven activity based costing in electronic industry. Journal of Modern Manufacturing Systems and Technology, 4(1), 68-81.

Zamrud, N.F., Abu, M.Y., Kamil, N.N.N.M. \& Safeiee, F.L.M. (2020). A comparative study of product costing by using activity-based costing (ABC) and time-driven activity-based costing (TDABC) method. International Manufacturing Engineering Conference \& The Asia Pacific Conference on Manufacturing Systems, 171-178.

Zheng, C.W. \& Abu, M.Y. (2019). Application of activity based costing for palm oil plantation. Journal of Modern Manufacturing Systems and Technology, 2, 1-14.

\section{CONFLICT OF INTEREST}

The author(s), as noted, certify that they have NO affiliations with or involvement in any organisation or agency with any financial interest (such as honoraria; educational grants; participation in speakers' bureaus; membership, jobs, consultancies, stock ownership, or other equity interest; and expert testimony or patent-licensing arrangements), or nonfinancial interest (such as personal or professional relationships, affiliations, expertise or beliefs) in the subject matter or materials addressed in this manuscript.

\section{AUTHORS' BIOGRAPHY}

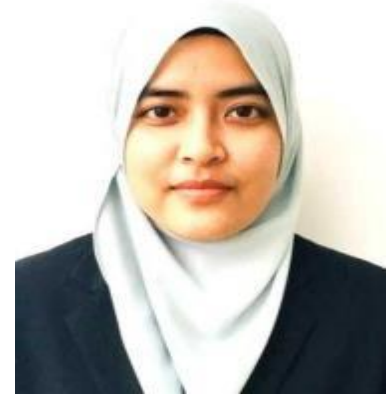

Author's Full Name: Nurul Farahin Zamrud Author's Email: N.FARAHINZ@GMAIL.COM

Author Professional Bio: Nurul Farahin is a research student at Faculty of Manufacturing \& Mechatronic Engineering Technology, Universiti Malaysia Pahang. 


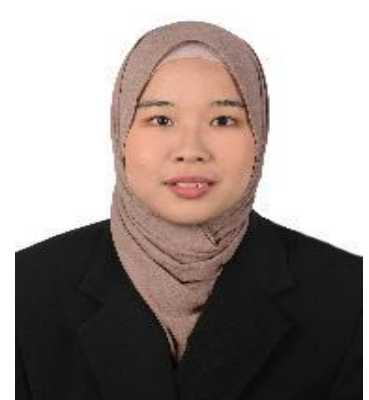

Author's Full Name: Sri Nur Areena Mohd Zaini Author's Email: areena5582@gmail.com

Author Professional Bio: Sri Nur Areena is a research student at Faculty of Manufacturing \& Mechatronic Engineering Technology, Universiti Malaysia Pahang.

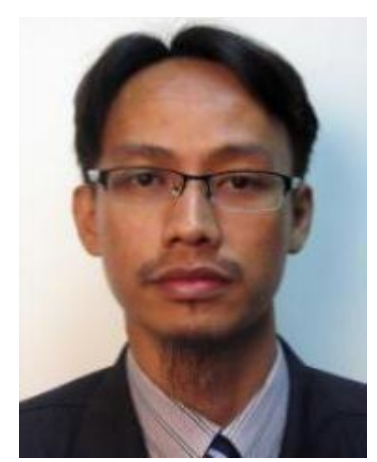

Author's Full Name: Mohd Yazid Abu Author's Email: myazid@ump.edu.my Author Professional Bio: Dr Mohd Yazid Abu is currently serving as a senior lecturer at Faculty of Manufacturing \& Mechatronic Engineering Technology, Universiti Malaysia Pahang. 